DOI: $10.17516 / 1997-1370-0835$

УДК 82.09

\title{
Where the Dialogue Ends: Problems of Reception of Russian Literature in China
}

\author{
Chzhao Siue and Iuliiia A. Govorukhina*b \\ aSichuan University \\ Chengdu, China \\ ${ }^{b}$ Baltic Naval Institute \\ Kaliningrad, Russian Federation
}

Received 12.08.2021, received in revised form 22.08.2021, accepted 14.09.2021

\begin{abstract}
The article is devoted to the phenomenon of the conflict of interpretations in the perception of the text by a foreign recipient. The study explores reasons for the difficulty of understanding unrealistic works in the Chinese readership and proposes a variant of improving the commentary as an intermediary text. The research is based on the methodological approaches and provisions of the theory of intercultural communication, discourse theory, receptive aesthetics and hermeneutics. As a result of the analysis of the judgments and assessments of Chinese students and specialists in Russian, we identified their main receptive difficulties: difficult understanding of the tropes, omission of allusions, lack of mastery of the language of a particular literary phenomenon. The reason for the latter is the absence of interpretive reading models, which have not been formed due to the longterm ignorance in China of Russian modernist literature. As a result, even today there are conflicts of interpretations, attempts to interpret an unrealistic text in a realistic paradigm. The outdated, ideologically «correct» intermediary texts should be replaced by a new type of commentary. Its model, proposed by the authors of this article, includes the following structural elements: information about the cultural and literary context; clarification of the semantics of words that are important for understanding the text; designation of national stereotypes that can lead to false interpretation and assessment of the text; step-by-step algorithm for working with text; list of references. Such a commentary will allow not only to remove lexical difficulties, but also to form interpretation skills.
\end{abstract}

Keywords: hermeneutics, text reception, reception of Russian literature in China, Russian studies, interpretation.

Research area: philology, literature studies.

Citation: Chzhao Siue, Govorukhina, Iu.A. (2021). Where the dialogue ends: problems of reception of Russian literature in China. J. Sib. Fed. Univ. Humanit. soc. sci., 14(10), 1509-1516. DOI: 10.17516/1997$1370-0835$

(C) Siberian Federal University. All rights reserved

* Corresponding author E-mail address: zhaoxue2018@163.com, yuliya_govoruhina@list.ru ORCID: 0000-0001-6477-1072 (Siue); 0000-0002-2675-5909 (Govorukhina) 


\title{
Там, где заканчивается диалог: проблемы рецепции русской литературы в Китае
}

\author{
Чжао Сюе ${ }^{\text {, Ю.А. Говорухинаб }}$ \\ ${ }^{a}$ Сычуаньский университет \\ Китай, Чэнду \\ ${ }^{\sigma}$ Балтийский военно-морской институт \\ Российская Федеращия, Калининград
}

\begin{abstract}
Аннотация. Статья посвящена явлению конфликта интерпретаций в ситуации восприятия текста инокультурным реципиентом. Изучаются причины сложности понимания нереалистических произведений русских авторов в китайской читательской аудитории, предлагается вариант усовершенствования комментария как текстапосредника. Исследование опирается на методологические подходы и положения теории межкультурной коммуникации, теории дискурса, рецептивной эстетики и герменевтики. В результате анализа суждений и оценок китайских студентов и русистов были выявлены их главные рецептивные сложности: затрудненное понимание тропики, пропуск аллюзий и других форм отсылок к контексту, невладение языком (способом кодирования) того или иного литературного явления. Причиной последнего служит отсутствие интерпретационных читательских моделей, которые не сформировались из-за продолжительного игнорирования в Китае русской модернистской литературы, чуждой идейно и эстетически. В результате и сегодня имеются конфликты интерпретаций, попытки интерпретировать нереалистический текст в реалистической парадигме. На смену устаревшим, идеологически «правильным» текстам-посредникам должен прийти новый тип комментария. Его модель, предложенная авторами статьи, включает следующие структурные элементы: информацию о культурном и литературном контексте, отраженном в произведении; прояснение семантики слов, важных для понимания текста; обозначение национальных стереотипов, которые могут привести к ложной интерпретации и оценке текста; пошаговый алгоритм работы с текстом; список литературы. Такой комментарий позволит не только снять лексические трудности, но и сформировать интерпретационные навыки.
\end{abstract}

Ключевые слова: герменевтика, рецепция текста, рецепция русской литературы в Китае, русистика, интерпретация.

Научная специальность: 10.01.00 - литературоведение.

\section{Introduction}

The time distance separating the writer and the text from the reader inevitably rises difficulties in reception. The new cultural background provokes the discovery of new meanings, actual context of the writer is not fully perceived, the allusions introduced are often indistinguishable. All that leads to a misunderstanding in significant aspects of the content. The situation is getting even more complicated in case of reception of foreign cultural texts. The difference in cultural contexts rises a conflict of interpretations.

Chinese students studying Russian language and literature often face difficulties in understanding fiction. Particular receptive difficulties happen when one gets acquainted with the works of the Silver Age and Russian postmodern literature. Some kind of intermediary texts that fill in the gaps in the understanding of Russian culture can help in solving this problem (on intercultural mediation discourse, see: 
Kulikova, 2019; Kulikova, Prokhorova, 2016). The creation of an effective intermediary text, however, is impossible without understanding specific difficulties of interpretation, reasons of not understanding the works. All this makes the topic of this article actual with both theoretical and practical significance.

The purpose of the article is to identify conflicting aspects of Russian text reception in the Chinese readership, to study reasons of misunderstanding, and to model the intermediary text.

A certain difficulty in fulfilling the objective is due to the near absence of material that would record the facts of misunderstanding: mistakes made by students, judgments of nonprofessional readers. We used the statements of students who study Russian literature in the bachelor's and master's degrees at Sichuan University. The materials were collected by teachers from the Chinese university. In addition, we used critical and literary articles of Russianists, responses of Chinese teachers of Russian literature.

\section{Theoretical framework}

The research is based on the methodological approaches of the theory of intercultural communication, discourse theory, receptive aesthetics and hermeneutics. The empirical analysis phase applied pragmatic-cognitive discourse analysis as a method of research and potential resolution of interculturally complicated conflicts (Van Dijk, 1978, 1989, Karasik, 2002, Dijk, 1997).

We are based on the following theoretical and methodological guidelines:

- the text perceived by the reader is a non-static system of potential meanings that arise under the influence of various social and cultural factors; the text has sections of «communicative uncertainty», the filling (concretization) of which leads to the success or failure of interpretation (Ingarden, 1962);

- the work appears at the moment of «meeting» with the recipient, and this process depends on the horizon of expectation of the reader (Iauss, 1994, Gadamer, 1988);

- the process of reception is associated with a partial transformation of the text, which is also due to national cultural attitudes.
The hermeneutic aspect of the problem of text misunderstanding challenges some foundations of the theory of communication. If we accept the multiplicity of interpretation of a fiction text, how do we determine whether communication is (un)successful? The conflict of interpretations is not a deviation from the norm, it can be productive, capable of generating a plurality of meanings. At the same time, if the reception of a text by a foreign cultural reader is complicated, there may be no productive increment of meanings. Moreover, the difficulties of reception can develop into unwillingness to continue reading the work and rejection from Russian literature and culture.

\section{Discussion}

The teaching of Russian literature at foreign universities often uses linguistic and cultural commentaries. These intermediary texts clarify the vocabulary of the text, idioms, social and cultural context. They are, however, universal and don't consider the national mental attitudes that guide the interpretation of the foreign cultural recipient. An investigation into the causes of interpretive failures makes it possible to create commentaries for readers with certain national receptive attitudes that set interpretation models.

\section{Perception of Russian texts \\ by the Chinese reader: \\ difficulties of reception and their reasons}

A comparative typological analysis of the oral and written judgments of Chinese students revealed some types of difficulties in understanding Russian literary works:

1. Misunderstanding in words and phrases. There are mostly polysemantic words that the author uses in the main meaning, idioms, tropes.

2. Allusions and other forms of actualization of the social and cultural context, consciously included by the author, are not recognised.

3. Lack of knowledge of the specific language (coding method) inherent in a particular literary movement. An especially difficult receptive situation develops when reading the Silver Age and postmodernist works. The rea- 
son is that Russian modernism as an aesthetic phenomenon was ignored in China during the 1950s and 1980s. The works of V. Bryusov, K. Bal'mont, F. Sologub, N. Gumiliov and others, which did not correlate with political attitudes and were aesthetically alien, have not been translated or studied. As a result, the Chinese reader has not mastered the specific modernist language of artistry. At the turn of the 20th and 21st centuries, Chinese Russian studies began to actively fill blank spots in the idea about stages of development of Russian literature and, of course, faced difficulties in understanding modernist texts and the worldview of their authors. Chzhou Ch. in his work «Study of Russian Literature of the Silver Age» confesses that the Silver Age is a significant literary heritage, but its overall view is still vague for Chinese readers. He is convinced that it is necessary to full this lacuna (Chzhou, 2003: 2). Van Ts. identifies Russian formalism, M. Bakhtin's theory and the literature of the Silver Age as the main gaps in the history and theory of 20th-century Russian literature (Van, 2010: 25).

Reading modernist works, Chinese students and teachers face a lack of understanding of the specific imagery of the texts, religious and philosophical concepts. Typical questions of students: «What idea did the author put into this text?», «Is the value of the Silver Age literature really that great?», «Why did literature that is so different from realism suddenly emerge at the turn of the century?»

Another reason for the difficulty of reception of the Russian modernism is the insufficient number of academic hours provided for the study of the Silver Age (4 academic hours in bachelor's and master's programmes). Bachelor's studies do not provide for reading modernist texts in the original language (Sichuan University offers translations of Maiakovsky's works). The master's programme involves acquaintance with Russian texts at the choice of the teacher (these are usually the works of Bely, Maiakovsky, Gippius, Briusov, Merezhkovsky, Bal'mont).

Another reason for the conflict of interpretations is the lack of understanding of the worldview of modernists and people in general from the turn of the 19th and 20th centuries. Setting to know the of Sologub's works, Chinese students fills confusion because of abundance of images of death, ask questions: "Why are the texts of the Silver Age so pessimistic?», «Why do decadents see the world this way?» For a long period of time (from 1930s to 1980s) Chinese Russianists estimated decadent literature, both Russian and Chinese, as depressive. For example, Chzhan Ch. in his monograph «Decadence in Chinese Literature of the end of 20th Century» (2005) describes decadent writers as dissatisfied with society but unable to change it and themselves, experiencing a spiritual crisis caused by the destruction of personal values and social ideals. At the same time, he notes that decadent writers have chosen the "wrong» aesthetic way of individualism and formalism. This view of decadence has turned into a disregard for the aesthetic finds of this literature.

Postmodernism is another phenomenon in Russian literature that is difficult to understand. The main reason for receptive difficulties, in our opinion, is a significant difference in cultural contexts. The lack of interpretive reading models leads to the confusion of Chinese students and teachers in the perception of game plots, a language game. They are looking for a perspective that would make it possible to rationally explain what is happening. For example, when reading Pelevin's novel «Chapaev and Emptiness», students required precision: when the hero is in a dream, and when he is in reality. Different forms of relativity cause confusion and misunderstanding.

The question about dialogue between postmodernism and the literary tradition is important for the Chinese reader. Another question is about the possible continuity that not only students, but also Russianists want to see. They have attitude to discovering productive forms of the tradition in modern literature and culture at the scale of the character and language of speaking about modernity. A clear break with tradition is estimated as a defeat, a dangerous tendency. For example, Li S. in his study «The Poetics of Russian Postmodern Literature» admits the importance of the effect of the deconstruction of ideology in postmodernism but points out that literature is being consumed by 
play, experimentation, which can kill the beauty (Li, 2008: 14).

The value orientation towards tradition leads to the fact that the latest literary works are estimated in the aspect of a productive or unproductive deviation from the classics. As a result, postmodern works are studied almost only at the level of the specific form of texts, analysis of the content is carried out in a «realistic» way. The Russianist U Ts. admits: «The Russian realistic literary tradition will comprehensively permeate into postmodern literature; therefore, we often interpret postmodern texts taking into account the realistic form» (U, 2004: 56).

Continuity, not only in art but also in all of existence, is an important national attitude of the Chinese. This explains, for example, such errors in reading Tolstaia's novel «Kys'»: «Pushkin in the novel is a sign of a return to Russian literary tradition, to classics», «The writer worries about the problem of loss of many cultural traditions of the past, loss of the continuity of generations», «Tolstaia's novel is about the preservation of tradition, it has more tradition than deconstruction», «The titles of the novel chapters are designated by the letters of the Russian alphabet. This is because the author aims to support Russian traditional culture».

Russianists also tend to see a productive dialogue with tradition in Tolstaia's novel. Researcher Siui L. («The artistic features of the Tatiana Tolstaia's novel «Kys'»»») is sure that the writer includes Pushkin in her text to reveal her lack of piety for the classics («classical things have only a shell, people do not care about the historical and cultural significance of the classics») and also to show that Pushkin must be firmly connected with modernity: «People cannot revive the country without understanding this person. Only by combining his concept of freedom, democracy, philanthropy with the postmodern impetuous life can the Russian tradition be reconstructed» (Siui, 2010: 22).

Chinese students hardly correlate such phenomena as modernism, avant-garde, postmodernism. Qualifying avant-garde literature as «very differing from traditional realism and conflicting with tradition», they classify postmodernism as an avant-garde. The reason for the lack of understanding, in our opinion, lies in the social, cultural and literary situation in China. Avant-garde literature appeared here only in the mid-to-late 1980s and was characterized as «postmodern» (Chen', 2015). By analogy with Chinese literature, students do not consider Russian postmodernism in association with modernism.

Obviously, the difficulties in perceiving Russian texts are explained not only by the level of language skills, but also by the idea of the social, cultural and literary context. They are associated with a lack of understanding of a particular aesthetic unrealistic language, with influence of national mental attitudes that guide the process of interpretation.

\section{Commentaries in teaching Russian literature in China: reality and prospects}

Russian studies are one of the actively developing areas in Chinese philology. Hundreds of thousands of students study Russian literature, but universities are unable to provide students with commentaries to works which make difficulties. The existing linguistic and cultural intermediary texts are outdated and represent an ideologically biased reading of the Russian literature. The textbook acts as a mediator. The most authoritative textbooks in China are the following.

Textbooks by Chinese authors: «History of the Russian Literature» (俄罗斯学史) Gen' G., Chzhan Ts., Iui I. (Beijing, 2003), «History of the Russian Literature» (俄国文学史) Chzhou M. (Shanghai, 1996), «History the of Russian Literature» (俄国文学史) Chzhen T. (Shanghai, 2019), «History of the Russian Literature of the 20th Century» (二十世纪俄罗斯文学史) Li Iu. (Beijing, 2000), «History of the Russian Literature of the 20th Century» (二十世纪俄罗斯文 学 史) Li Kh., Chzhan Ts. (Chindang, 2004), «Russian Literature of the 20th Century: Ideological Currents and Directions» (二十世纪俄 罗斯文学: 思潮 与流派) Chzhan Ts., Wan Ts., U Ts. (Beijing, 2012), «Literary Magic Square: Russian Literature of the 20th Century» (文 学魔方一二十世纪的俄罗斯文学) Liu V. (Beijing, 2004). 
Textbooks by Russian authors translated into Chinese: "History of the Russian Literature of the 20th Century (20-90s): Major Names» (二十世纪俄罗斯文学史), ed. S. I. Kormilova (translators: Chzhao D., Duan' L., Khu S., Nanjing, 2017); "History of the Russian Literature» (俄国文学史) Mirskii D. S. (translator Liu V., Beijing, 2020); «Russian literature of the XX century» (20 世纪俄罗斯文 学) V.V. Agenosov (translator Lin' Ts., Beijing, 2001).

Translations of the Silver Age works with commentaries make the texts easier to understand and act as intermediaries. There are commentaries explaining mythological plots and symbols (Chzhen' T. «Selected Russian Modernist Poems» (1996)); commentaries clarifying religious images and plots $(\mathrm{Su} \mathrm{Kh}$. «Selected Tsvetaeva's essays» (2012); explaining real personalities, toponyms (for example, an explanation about James Cooper is added to the translation of «The Gnome» by Sologub (Liu K., Chzhou Ch. «Selected Works of Russian Symbolism» (2017)); commentaries on the specific realities of Russian life; commentaries explaining the essence of intertextual and verbal play (in translation of Tolstaia's novel «Kys'» (Chen' S., 2005), Pelevin's «Generation P» (Liu V., 2018).

These types of commentaries can remove some difficulties of text reception; however, they work only with the vocabulary: tropes, toponyms, anthroponyms, etc. Identified reasons of misunderstanding of unrealistic works allow us to conclude that comments can and should include interpretive models, hermeneutic «hints». Of course, there is no universal interpretation which could be imposed on any symbolist text, for example. It is possible, however, to set the perspective of vision of the text written by the language of symbolism or postmodernism.

\section{Updated commentary model}

Three subjects / objects participate in the process of interpreting a work: a writer, a work, a reader. The «author» assumes the presence of such text-generating moments as worldview, value and aesthetic attitudes, social and cultural context, which are manifest- ed in the fiction text and turn out to be meaningfully important. They often become the reason for the misunderstanding of the work by the reader. The phrase «I don't understand this text» implies «I don't know important values for the author», «I don't know the context», «I don't know the peculiarities of the language of particular time».

The element «reader» is represented by combination of components of the horizon of expectation, pre-understanding poses (cultural stereotypes, value attitudes), models of fiction work reception (the reading experience of the Chinese reader is dominated by the model of reception of realistic literature).

«Text» is not a static element of communication. It multiplies depending on the subject who «meets» it, as well as depending on the influence of intermediary texts (critical articles, textbooks, reviews of other readers).

Thus, this communication chain contains such units that can potentially cause a conflict of interpretations (significant discrepancy or contradiction between the pledged and the extracted meaning). It is these out-of-the-text elements that should underlie the model of an intermediary text, which would take a special place in the communication chain.

A commentary acting as an intermediary between a text and a foreign reader, a mediator commentary, must take into account the multi-context nature of communication, the difference in values in intercultural communication, be based on general presuppositions, enter new senses in the addressee's senses field, rebuild the senses fields, change semantic field, set interpretive models that could be applied to other texts of the same aesthetic tradition or the same author. It should be oriented towards the reader of a certain national culture with his stereotypes, expectations, and customary ideas about modelling the artistic world.

In our understanding, the updated commentary, the mediator commentary, should have the following structure.

The first part of the commentary contains information about the cultural and literary context reflected in the work. An important principle of compiling this part should not be the 
completeness of the formed concept of the context but the relevance for this work.

The next part is to clarify the semantics of words which are important for understanding the text. When working on this part of the commentary, care should be taken to select the words to be explained. The use of a word in a figurative meaning recorded in the dictionary should not be a reason for inclusion in a commentary (determining actual meaning of the word in a dictionary is an important translation skill that does not require hints). At the same time, difficult tropes, uncommon idioms can cause difficulties and must be semantically refined.

The third part is the designation of national stereotypes that can lead to false interpretation and assessment. The work on this part is especially difficult, must rely on the existing incorrect interpretations of the texts, requires the skill of reconstructing national receptive attitudes and modelling the horizon of expectation of the reader.

The fourth element of the commentary is a step-by-step algorithm for working with text. This part of the commentary should be not «ready-made» interpretation of the work but a system of tasks, the implementation of which will lead to its understanding. As a result, a hermeneutic model will remain in the mind of the reader. It will make it possible to under- stand other texts created in a certain aesthetic system.

The final part of the commentary offers a list of references to help expand the understanding of the work.

The described model of the commentary is the result of a theoretical understanding of the problem of the Chinese recipient's misunderstanding of Russian unrealistic literature. The next stage of work is the creation of an experimental example, its approbation, and the study of its effectiveness.

\section{Conclusion}

Intercultural dialogue, the importance of which is discussed by politicians, scientists and artists (Nigmatullina, 2018), can be interrupted at points of various hermeneutic failures. One of them, connected with the conflict of interpretations of foreign cultural texts, can be resolved. A new type of commentary can perform a mediating function between a foreign reader and an author/book. It not only removes some difficulties in reception the vocabulary of the text, but also sets receptive (hermeneutic) models applicable to the texts of one «aesthetic language». The development of such a commentary requires an interdisciplinary approach, study of the difficulties of reception a foreign cultural text and its causes.

\section{References}

Chen', C. (2005). Kys'. Shanghai, Ywen, 326 p.

Chen', S. (2015). Postmodernism in Chinese avant-garde literature. Guilin, Guangxi Normal University Press, 464 p.

Chzhan, Ch. (2005). Decadence in Chinese Literature of the Late 20th Century. Hefei, Anhuai University Press, $312 \mathrm{p}$.

Chzhen, T. (1996). Selected Russian Modernist Poems, Shanghai, Ywen, 528 p.

Chzhou, Ch. (2003). Study of Russian literature of the Silver Age. Beijing, Peking University Press, 2003, 255 p.

Dijk, T.A. van (1997). The study of discourse, In Discourse studies: A multidisciplinary introduction. 2, 1-34.

Gadamer, Kh.-G. (1988) Istina i metod: Osnovy filosofskoi germenevtiki [Truth and Method: Fundamentals of Philosophical Hermeneutics]. Moscow, Progress, 704 p.

Iauss Kh.-R. (1994). K probleme dialogicheskogo ponimaniia [To the problem of dialogical understanding], In Voprosy filosofii [Philosophy questions], 12, 97-106.

Ingarden, R. (1962) Issledovanie po estetike [Research on aesthetics]. Moscow, Foreign literature, $569 \mathrm{p}$. 
Karasik, V.I. (2004) Iazykovoi krug: lichnost', konzepty, diskurs [Language circle: personality, concepts, discourse]. Volgograd, Peremena, 389 p.

Kulikova, L.V. (2019). Diskurs mezhkul'turnoi mediazii: konzeptual'naia model' issledovaniia [Intercultural Mediation Discourse: A Conceptual Research Model], In Vestnik SPbGU [Bulletin of St. Petersburg State University. Language and Literature]. 16 (2), 245-258.

Kulikova, L.V., Prokhorova, O. A. (2016). Issledovatel'skie podkhody k diskursu mediatsii $\mathrm{v}$ fokuse mezhdistsiplinarnosti [Research approaches to the discourse of mediation in a focus of interdisciplinarity], In Filologicheskie nauki. Voprosy teorii i praktiki [Philological sciences. Questions of theory and practice]. 2(56), 100-104.

Li, S. (2008). Poetics of Russian Postmodern Literature In Russian Literature and Art. 2, 9-14.

Liu, K., Chzhou, Ch. (2017) Selected Works of Russian Symbolism Hangzhou: Zhejiang Literary Publishing House. $425 \mathrm{p}$.

Liu, V. (2018). Generation P. Beijing, October, 379 p.

Nigmatullina, T.A., Ternovaia L.O. (2018). Politicheskaia mediatsiia [Political mediation]. Moscow, Iurait, $327 \mathrm{p}$.

Siui, L. (2010). Artistic features of the novel «Kys» by Tatiana Tolstoy: Shanghai, Iven', 43 p.

$\mathrm{Su}$, Kh. (2012). Selected Essays by M. Tsvetaeva. Guilin, Guangxi Normal University Press. $237 \mathrm{p}$.

U, Ts. (2004). Russian postmodern literature and Russian national cultural tradition [Russkaia postmodernistskaia literatura i russkaia natsionalnaia kul'turnaia traditsiia]. In Kritika zarubezhnoi literatury, 3, 50-56.

Van Deik, T.A. (1978) Voprosy pragmatiki teksta [Questions of pragmatics of the text], In Novoe v zarubezhnoi lingvistike [New in foreign linguistics]. 8, 259-336.

Van Deik, T.A. (1989) Iazyk. Poznanie. Kommunikatsiia [Language. Cognition. Communication]. Moscow, Progress, $310 \mathrm{p}$.

Van, Ts. (2010) Reception of Russian literature and its modern interpretation in the context of Chinese literature of the 20th century. Beijing: Beijing Normal University Press, 322 p. 